\title{
OCCURRENCE OF PESTICIDES IN THE WHITE RIVER, INDIANA, 1991-95
}

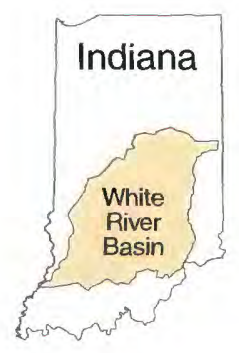

\begin{abstract}
Pesticides (herbicides and insecticides) are used extensively in the White River Basin. Application of herbicides to corn and soybeans accounts for most of the use. The pesticides most frequently detected near the mouth of the White River during 1991-95 were the herbicides alachlor, atrazine, cyanazine, and metolachlor. The highest concentrations of herbicides in the river were typically found during late spring runoff following application. Generally, concentrations of alachlor have been decreasing while concentrations of acetochlor have been increasing in response to changes in the use of these herbicides in the basin. The total amount of the commonly used herbicides transported by the river is about 1 percent or less of the amount applied to cropland. Insecticides commonly used in urban and agricultural areas also were found but in much lower concentrations than commonly used herbicides.
\end{abstract}

\section{INTRODUCTION}

In 1991, the U.S. Geological Survey began the National WaterQuality Assessment (NAWQA) Program. The long-term goals of the NAWQA Program are to describe the status and trends in the quality of a large, representative part of the Nation's surface- and ground-water resources and to provide a sound, scientific understanding of the primary natural and human factors affecting the quality of these resources (Hirsch and others, 1988).

The White River Basin in Indiana was among the first 20 river basins to be studied as part of this program. A major component of the White River Basin study is to determine the occurrence of pesticides in the White River. This paper presents the findings from pesticide data collected from one site near the mouth of the river from May 1991 through September 1995.

\section{DESCRIPTION OF THE WHITE RIVER BASIN}

The White River Basin is part of the Mississippi River system and drains 11,350 square miles of central and southern Indiana (fig. 1). Longterm average streamflow is about 12,300 cubic feet per second near the White River's confluence with the Wabash River in southwestern Indiana. Variations in streamflow are generally moderate and seasonal.

Streamflow is typically highest in April and May and lowest in late summer and fall. Average annual precipitation within the study area ranges from 40 inches in the northern part of the basin to 48 inches in the southcentral part of the basin and usually is distributed evenly throughout the year. Rainfall in the winter and early spring is generally of long duration, steady, and of mild intensity, whereas late spring and summer rainfall tends to be of short duration and high intensity.

The population of the White River Basin in 1990 was approximately 2.1 million people, about three-fourths of which are concentrated in the northern part of the basin. The Indianapolis Metropolitan Area accounts for about 60 percent of the total population. About 85 percent of publicwater supply is from surface-water sources. The primary land use in the basin is agriculture (fig. 2) which accounts for about 70 percent of the basin. Extensive soybean and corn production occurs in the northern, southwestern, and southeastern parts of the basin. In 1992, about 22 percent of the basin was planted in corn, and about 18 percent was planted in soybeans. These two crops accounted for 78 percent of all cropland. Other crops account for a much smaller percentage of the basin and include hay (about 3 percent) and wheat (about 2 percent) and, to a much lesser extent

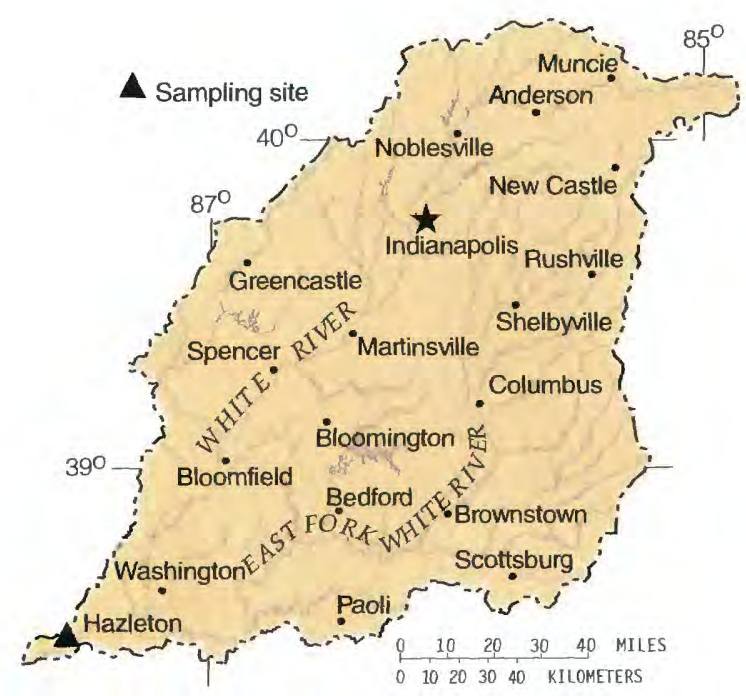

Figure 1. The White River Basin.

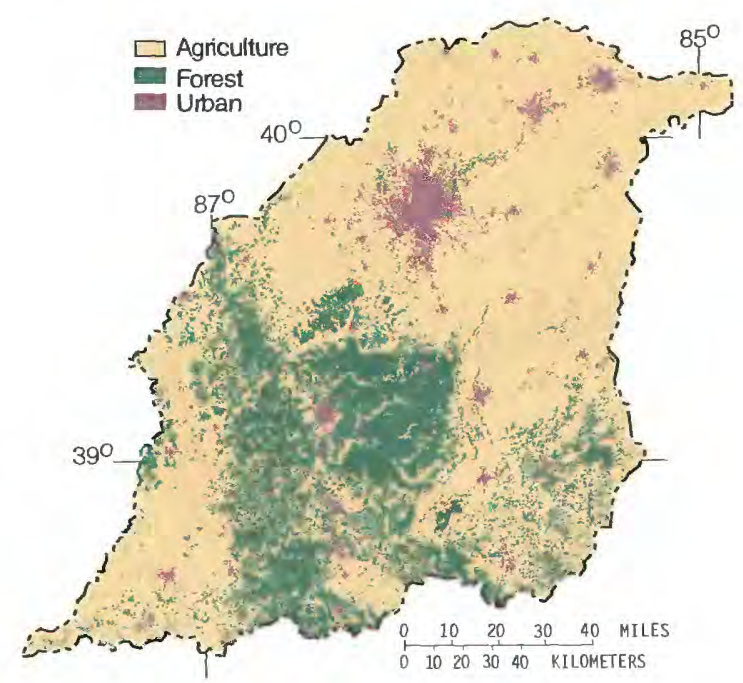

Figure 2. Land use in the White River Basin. 
apples, barley, cucumbers, green beans, melons, oats, potatoes, pumpkins, rye, sorghum, strawberries, tobacco, and tomatoes (each less than 0.1 percent). The south-central part of the basin is not farmed as extensively as other parts because of the hill and valley landscape. Most of the forested land in the basin is located in this region. There is significant industrialization in the cities of Indianapolis, Muncie, and Anderson.

\section{PESTICIDE USE IN THE WHITE RIVER BASIN}

Herbicides applied to corn and soybeans dominate pesticide use in the White River Basin. Herbicides are applied in the spring during planting to virtually all of the corn and soybean crop. Triazine (primarily atrazine and cyanazine) and acetanilide (alachlor and metolachlor) compounds are the most commonly used herbicides. Acetochlor, a new corn herbicide, is beginning to be used in the basin. Acetochlor was conditionally registered by the U.S. Environmental Protection Agency (USEPA) in 1994 (Stephen Johnson, U.S. Environmental Protection Agency, written communication, 1994). It is expected that use of acetochlor will significantly reduce total amounts of herbicides used in the United States, and its continued registration is conditional on this reduction. Even before the registration of acetochlor, the use of alachlor had been decreasing in Indiana. Use of alachlor on corn and soybeans decreased by about 30 percent between 1990 and 1993 in central and southern Indiana (fig. 3). An even larger percentage decrease during this time occurred in
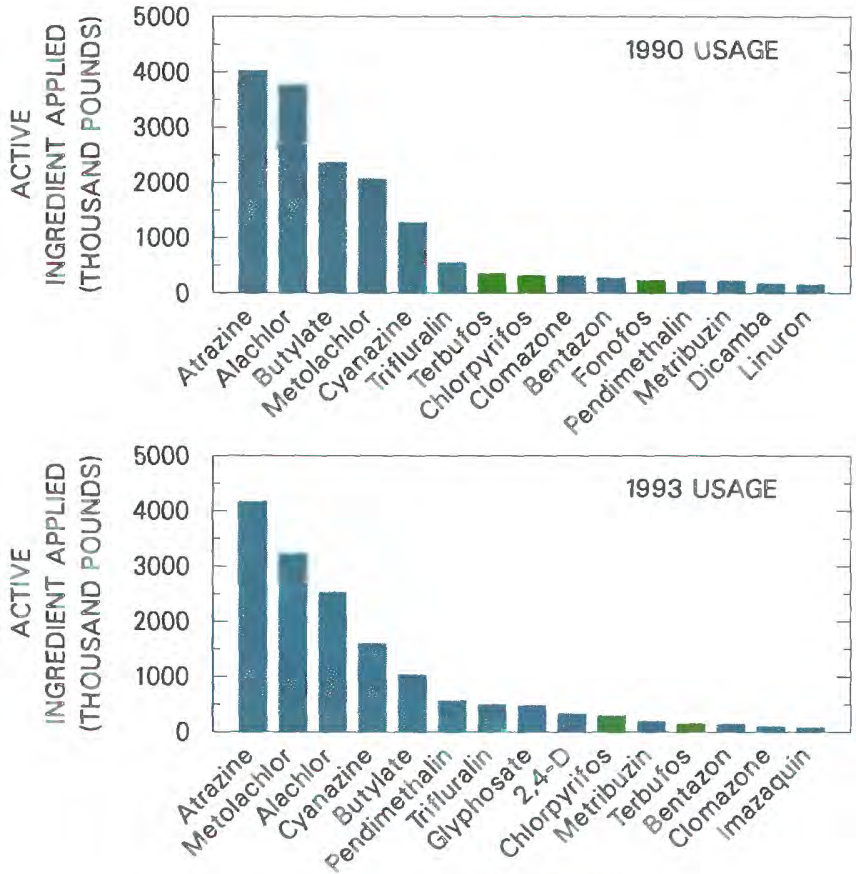

EXPLANATION

HERBICIDE INSECTICIDE

Figure 3. Use of the 15 most common pesticides on corn and soybeans in central and southern Indiana in 1990 and 1993 (source of data: Indiana Agricultural Statistics Service, 1991 and 1994).

the use of butylate, another common herbicide. Use of metolachlor and cyanazine increased during the same time period. Because of increased use of no-till farming practices in the basin, there has been a significant increase in the use of glyphosate and 2,4-D. These herbicides are used prior to planting to kill all plant growth. Insecticides are applied during the summer to about 25 percent of the corn crop and typically are not applied to soybeans.

The estimated agricultural use of pesticides in the White River Basin is shown in table 1. About 96 percent of the total agricultural pesticide use in the basin is on corn and soybeans (Anderson and Gianessi, 1995).
Table 1. Estimated agricultural pesticide use in the White River Basin

[1992-94 average annual usage except acetochlor which is 1994 usage. Source of data: Anderson and Gianessi, 1995]

\begin{tabular}{|c|c|c|c|c|c|}
\hline Pesticide & $\begin{array}{l}\text { Active } \\
\text { ingredient } \\
\text { applied } \\
\text { (thousand } \\
\text { pounds) }\end{array}$ & Rank & Pesticide & $\begin{array}{l}\text { Active } \\
\text { ingredient } \\
\text { applied } \\
\text { (thousand } \\
\text { pounds) }\end{array}$ & Rank \\
\hline \multicolumn{6}{|c|}{ Herbicides } \\
\hline 2,4-D & 265 & 8 & Ethalfluralin & 38 & 17 \\
\hline Acetochlor & 125 & 10 & Glyphosate & 361 & 6 \\
\hline Acifluorfen & 24 & 22 & Imazaquin & 44 & 16 \\
\hline Alachlor & 1,250 & 3 & Imazethapyr & 27 & 21 \\
\hline Atrazine & 2,220 & 1 & Linuron & 79 & 14 \\
\hline Bentazon & 143 & 9 & Metolachlor & 2,070 & 2 \\
\hline Butylate & 887 & 4 & Metribuzin & 74 & 15 \\
\hline Clomazone & 32 & 20 & Paraquat & 36 & 18 \\
\hline Cyanazine & 791 & 5 & Pendimethalin & 357 & 7 \\
\hline Dicamba & 113 & 11 & Simazine & 35 & 19 \\
\hline EPTC & 83 & 13 & Trifluralin & 102 & 12 \\
\hline \multicolumn{6}{|c|}{ Insecticides } \\
\hline Acephate & 2.1 & 13 & Malathion & 4.1 & 12 \\
\hline Azinphos-methyl & 1.3 & 17 & Methyl parathion & 1.7 & 15 \\
\hline Carbaryl & 14 & 8 & Oil & 45 & 4 \\
\hline Carbofuran & 44 & 5 & Permethrin & 11 & 9 \\
\hline Chlorpyrifos & 154 & 2 & Phorate & 39 & 6 \\
\hline Diazinon & 1.0 & 19 & Phosmet & 1.2 & 18 \\
\hline Dimethoate & 5.1 & 11 & Propargite & 2.0 & 14 \\
\hline Endosulfan & 1.4 & 16 & Tefluthrin & 6.8 & 10 \\
\hline Fonofos & 163 & 1 & Terbufos & 85 & 3 \\
\hline Formetanate hydrochloride & .7 & 20 & Trimethacarb & 19 & 7 \\
\hline
\end{tabular}

Fungicide and insecticide use on apples, tomatoes, and watermelons (2.2 percent of use) and herbicide use on wheat, pasture, and hay ( 1.0 percent of use) accounts for most of the remaining agricultural pesticide use.

Nonagricultural use of pesticides in the White River Basin is not as well documented as agricultural use. Insecticides typically account for a larger percentage of the total amount of pesticides used in urban areas than in agricultural areas (Hodge, 1993). The insecticides allethrin, chlorpyrifos, diazinon, lindane, malathion, and propoxur, and the herbicides 2,4-D, MCPP, and glyphosate commonly are used in urban areas.

\section{STUDY APPROACH}

Collection of water samples for measurement of pesticide concentrations in the White River began in May 1991. Samples were collected at Hazleton, Ind., approximately 19 miles from the mouth of the river (fig. 1). This site includes the drainage from all but 45 square miles of the 11,350-square-mile White River Basin. Samples were collected twice weekly to twice monthly during May through August and approximately monthly during the rest of the year with procedures described by Shelton (1994). Samples were analyzed by the U.S. Geological Survey National Water Quality Laboratory primarily for triazine and acetanilide herbicides in 1991 and early 1992. Beginning in May 1992, the number of compounds analyzed for was expanded to include many herbicides and insecticides commonly used in the White River Basin. Acetochlor was included beginning in April 1994. Gas chromatography/mass spectrometry methods were used to measure dissolved pesticide concentrations in water samples collected from the river (Sandstrom and others, 1992; Zaugg and others, 1995).

\section{FINDINGS}

A summary of the results of pesticide sampling in the White River at Hazleton, Ind., is presented in table 2. The herbicides atrazine and meto- 
Table 2. Occurrence of selected herbicides and insecticides in the White River at Hazleton, Ind., 1991-95

[< symbol indicates less than]

\begin{tabular}{|c|c|c|c|c|c|c|}
\hline Pesticide & $\begin{array}{l}\text { Num- } \\
\text { ber of } \\
\text { sam- } \\
\text { ples }\end{array}$ & $\begin{array}{c}\text { Num- } \\
\text { ber of } \\
\text { detect- } \\
\text { ions }\end{array}$ & $\begin{array}{l}\text { Maximum } \\
\text { concen- } \\
\text { tration } \\
\text { (micro- } \\
\text { grams per } \\
\text { liter) }\end{array}$ & $\begin{array}{l}\text { Num- } \\
\text { ber of } \\
\text { sam- } \\
\text { ples }\end{array}$ & $\begin{array}{l}\text { Num- } \\
\text { ber of } \\
\text { detect- } \\
\text { ions }\end{array}$ & $\begin{array}{l}\text { Maximum } \\
\text { concen- } \\
\text { tration } \\
\text { (micro- } \\
\text { grams per } \\
\text { liter) }\end{array}$ \\
\hline & \multicolumn{3}{|c|}{ May-July } & \multicolumn{3}{|c|}{ August-April } \\
\hline \multicolumn{7}{|c|}{ Herbicides } \\
\hline Acetochlor & 19 & 16 & 0.61 & 16 & 9 & 0.28 \\
\hline Alachlor & 73 & 66 & 3.2 & 83 & 43 & .39 \\
\hline Atrazine & 73 & 73 & 11. & 83 & 83 & 1.9 \\
\hline Benfluralin & 47 & 0 & $<.01$ & 59 & 2 & .01 \\
\hline Butylate & 71 & 45 & .08 & 83 & 21 & .03 \\
\hline Cyanazine & 73 & 65 & 5.1 & 83 & 43 & .60 \\
\hline DCPA & 47 & 22 & .05 & 59 & 7 & .05 \\
\hline EPTC & 71 & 28 & .03 & 83 & 4 & .01 \\
\hline Ethalfluralin & 47 & 0 & $<.01$ & 59 & 0 & $<.01$ \\
\hline Linuron & 71 & 14 & .12 & 83 & 1 & .05 \\
\hline Metolachlor & 73 & 73 & 4.9 & 83 & 80 & 1.7 \\
\hline Metribuzin & 73 & 49 & .38 & 83 & 10 & .22 \\
\hline Napropamide & 47 & 1 & .01 & 59 & 2 & .02 \\
\hline Pebulate & 47 & 1 & .01 & 59 & 1 & .01 \\
\hline Pendimethalin & 71 & 19 & .03 & 83 & 1 & .02 \\
\hline Prometon & 73 & 58 & .20 & 83 & 62 & .19 \\
\hline Propachlor & 71 & 5 & .04 & 83 & I & .02 \\
\hline Simazine & 73 & 70 & .72 & 83 & 68 & .46 \\
\hline Tebuthiuron & 47 & 36 & .03 & 59 & 31 & .04 \\
\hline Trifluralin & 71 & 27 & .01 & 83 & 10 & .01 \\
\hline \multicolumn{7}{|c|}{ Insecticides } \\
\hline Chlorpyrifos & 71 & 16 & .13 & 83 & 12 & .03 \\
\hline Diazinon & 71 & 56 & .05 & 83 & 51 & .18 \\
\hline Dieldrin & 71 & 1 & .05 & 83 & 1 & .05 \\
\hline Ethoprop & 71 & 1 & .02 & 83 & 1 & .02 \\
\hline Fonofos & 71 & 31 & .03 & 83 & 3 & .01 \\
\hline Lindane & 71 & 1 & .02 & 83 & 0 & $<.02$ \\
\hline Malathion & 71 & 5 & .02 & 83 & 2 & .02 \\
\hline Methyl parathion & 71 & 1 & .04 & 83 & 0 & $<.04$ \\
\hline Phorate & 71 & 0 & $<.06$ & 83 & 0 & $<.05$ \\
\hline Propargite & 47 & 0 & $<.02$ & 59 & 0 & $<.02$ \\
\hline Terhufos & 71 & 0 & $<.05$ & 83 & 0 & $<.05$ \\
\hline
\end{tabular}

lachlor were the most commonly detected pesticides in the river. Atrazine was detected in each of the 156 samples collected. Metolachlor was detected nearly as often. Atrazine concentrations were as high as $11 \mu \mathrm{g} / \mathrm{L}$ (micrograms per liter) and metolachlor concentrations were as high as $4.9 \mu \mathrm{g} / \mathrm{L}$. Other herbicides detected in appreciable concentrations (maximum concentration greater than or equal to $0.2 \mu \mathrm{g} / \mathrm{L}$ ) were acetochlor, alachlor, cyanazine, metribuzin, prometon, and simazine. These compounds typically were detected during the growing season and less often or not at all during the rest of the year. Butylate, another commonly used herbicide, was not found as often and only at low concentrations. Decreasing alachlor concentrations in the White River (fig. 4) reflect the decreasing use of this herbicide in the basin (fig. 3). Likewise, increasing concentrations of acetochlor in the White River (fig. 5) reflect increasing use of this herbicide in the region. Diazinon and fonofos were the most commonly detected insecticides, although the maximum concentrations of these insecticides were substantially less than the maximum herbicide concentrations. The maximum insecticide concentration found $(0.18 \mu \mathrm{g} / \mathrm{L}$ for diazinon) was approximately 60 times less than the maximum herbicide concentration found. Herbicide concentrations were highest in late spring or early summer. The highest concentrations typically occurred during the first one or two periods of runoff following ap-

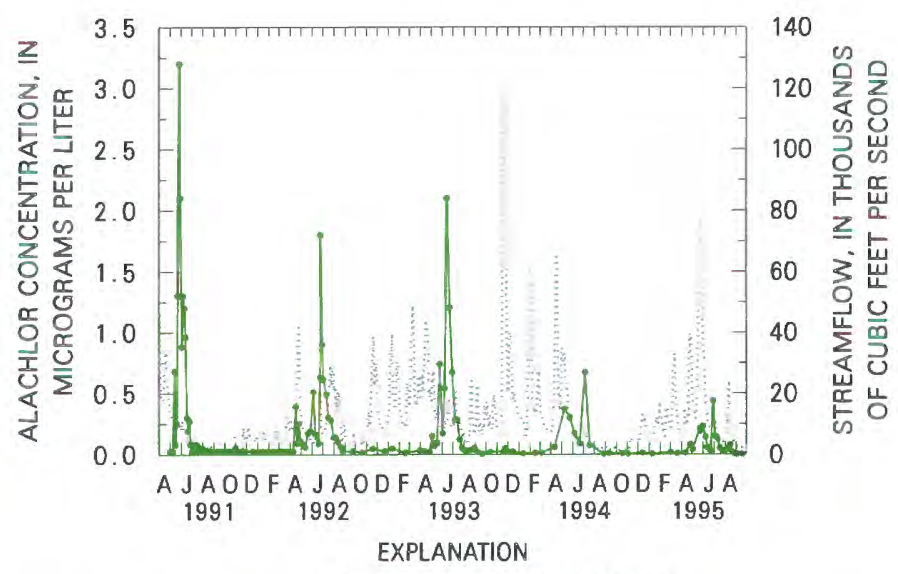

$\longrightarrow$ ALACHLOR STREAMFLOW

Figure 4. Relation of alachlor concentration and streamflow to time in the White River at Hazleton, Ind.

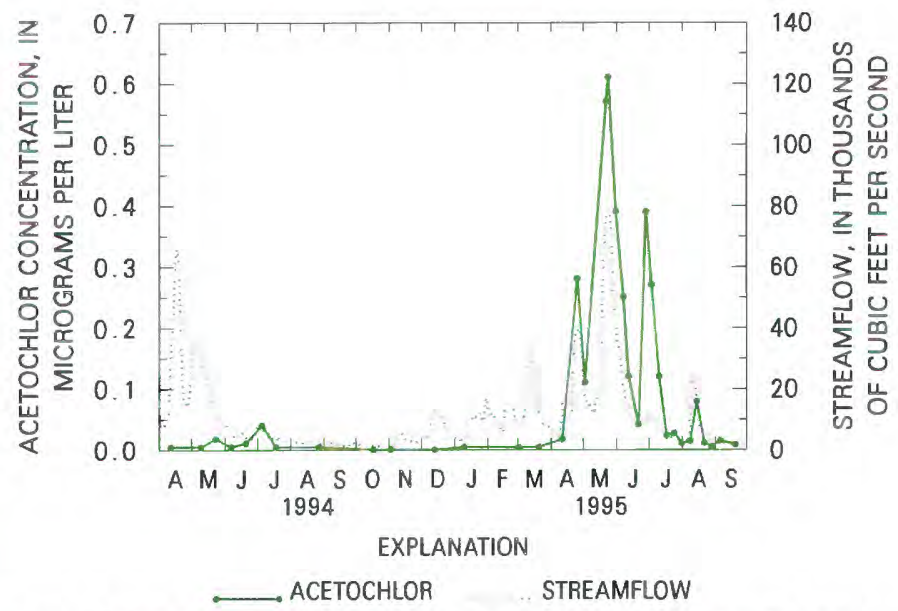

Figure 5. Relation of acetochlor concentration and streamflow to time in the White River at Hazleton, Ind.

plication. The seasonal pattern in atrazine concentrations in the White River (fig. 6) was typical of the pattern observed for most of the commonly used herbicides. The timing of peak herbicide concentrations in the river was a function of weather conditions prior to application and rainfall-runoff patterns after application. High herbicide concentrations tend to be associated with rising streamflow when it occurs during the several weeks following application and not associated with streamflow during the rest of the year (figs. 4-6). Figure 7 shows the effect of two different conditions on the timing of peak atrazine concentrations. In 1991, temperatures were above normal and rainfall was near or below normal in April, enabling farmers to plant in late April and early May. Peak atrazine concentrations were associated with the runoff that occurred in late May, even though there was only a relatively small increase in streamflow. Conditions were significantly different in 1992. Belownormal temperatures in April and May and 18 continuous days of rain in April prevented most farmers from planting until the latter half of May, especially in the northern, intensively farmed part of the basin. Following planting, little runoff occurred until late June, and peak atrazine concentrations were once again associated with increased runoff.

The amount of the commonly used herbicides transported by the river was a small fraction of the total amount applied to cropland in the basin (table 3 ). Slightly more than 1 percent of the atrazine applied was transported by the river. The percentage transported for other compounds was even less. Only about 0.1 percent of the butylate applied was transported. Few data are available to determine whether decomposition compounds of these herbicides are an appreciable form of transport. Carter and others 


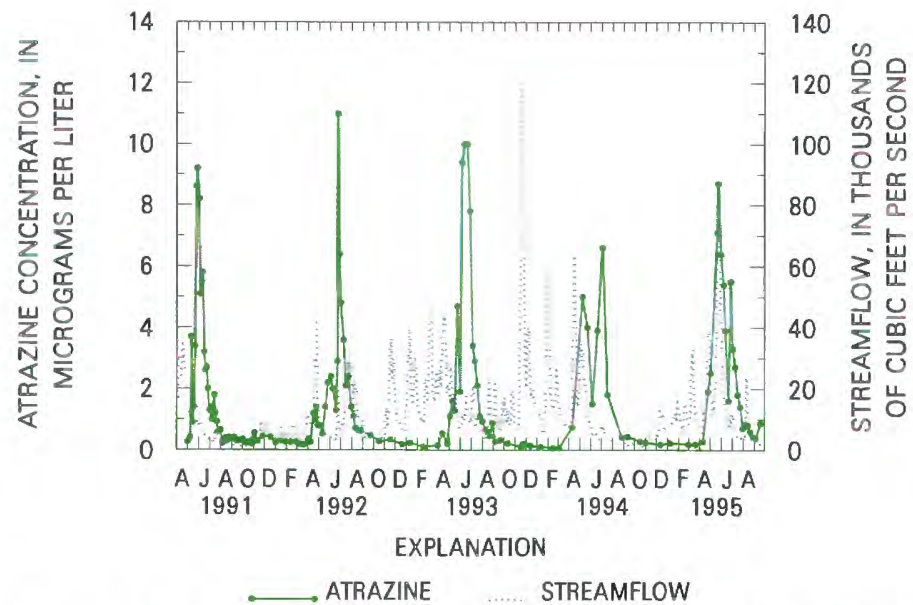

Figure 6. Relation of atrazine concentration and streamflow to time in the White River at Hazleton, Ind.

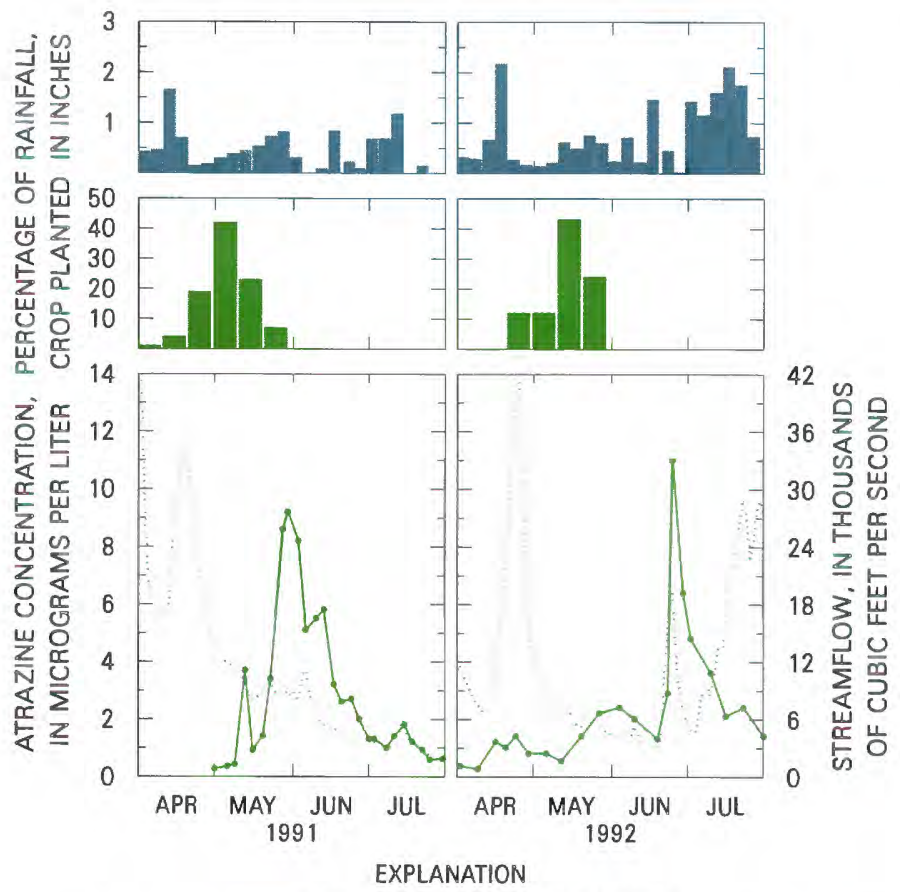

ATRAZINE

STREAMFLOW

Figure 7. Effect of rainfall, planting progress, and streamflow in the White River Basin on atrazine concentration in the White River at Hazleton, Ind. (Rainfall shown is average of amounts recorded at 16 selected National Weather Service stations distributed throughout the basin. Percentage of crop planted shows the percentage of the corn crop planted in the 10-day period represented by the width of the bar.)

(1995) indicate that for atrazine in the White River, transport of decomposition compounds was less than the transport of atrazine.

\section{REFERENCES}

Anderson, J.A., and Gianessi, L.P., 1995, Pesticide use in the White River Basin: National Center for Food and Agricultural Policy, 99 p.

Carter, D.S., Lydy, M.J., and Crawford, C.G., 1995, Water-quality assessment of the White River Basin, Indiana-Analysis of available information on pesticides, 1972-92: U.S. Geological Survey WaterResources Investigations Report 94-4024, 60 p.
Table 3. Estimated average annual load in the White River at Hazleton, Ind., for the five most widely used pesticides (1992-94)

\section{[< symbol indicates less than]}

\begin{tabular}{|l|c|c|}
\hline \multicolumn{1}{|c|}{ Pesticide } & $\begin{array}{c}\text { Annual load } \\
\text { (pounds) }\end{array}$ & $\begin{array}{c}\text { Percent of 1992-94 } \\
\text { average annual } \\
\text { usage in basin }\end{array}$ \\
\hline Alachlor & 3,000 & 0.2 \\
\hline Atrazine & 28,000 & 1.3 \\
\hline Butylate & 190 & $<0.1$ \\
\hline Cyanazine & 5,900 & 0.7 \\
\hline Metolachlor & 13,000 & 0.6 \\
\hline
\end{tabular}

Hirsch, R.M., Alley, W.M., and Wilber, W.G., 1988, Concepts for a National Water-Quality Assessment Program: U.S. Geological Survey Circular 1021, $42 \mathrm{p}$.

Hodge, J.E., 1993, Pesticide trends in the professional and consumer markets, in Racke, K.D., and Leslie, A.R., eds., Pesticides in Urban Environments-Fate and Significance: Washington, D.C., American Chemical Society, p. 11-17.

Indiana Agricultural Statistics Service, 1991, 1990 Agricultural Chemical Use Survey: Indiana Agriculture Report, v. 11, no. SP-5, 8 p.

Indiana Agricultural Statistics Service, 1994, 1993 Agricultural Chemical Use Survey: Indiana Agriculture Report, v. 14, no. SP-5, 8 p.

Sandstrom, M.W., Wydoski, D.S., Schroeder, M.P., Zamboni, J.L., and Foreman, W.T., 1992, Methods of Analysis by the U.S. Geological Survey National Water Quality Laboratory-Determination of organonitrogen herbicides in water by solid-phase extraction and capillary-column gas chromatography/mass spectrometry with selected-ion monitoring: U.S. Geological Survey Open-File Report 91-519, 34 p.

Shelton, L.R., 1994, Field guide for collecting and processing streamwater samples for the National Water-Quality Assessment Program: U.S. Geological Survey Open-File Report 94-455, 42 p.

Zaugg, S.D., Sandstrom, M.W., Smith, S.G., and Fehlberg, K.M., 1995, Methods of Analysis by the U.S. Geological Survey National Water Quality Laboratory-Determination of pesticides in water by C-18 solid-phase extraction and capillary-column gas chromatography/mass spectrometry with selected-ion monitoring: U.S. Geological Survey Open-File Report 95-181, 49 p.
U.S. Geological Survey Fact Sheet 233-95

Prepared by

Charles G. Crawford

For more information, contact:

Project Chief

White River Basin Study

U.S. Geological Survey

5957 Lakeside Boulevard

Indianapolis, IN 46278-1996

317-290-3333 